\title{
LIQUIDITY MANAGEMENT PRACTICES OF SMALL AND MEDIUM-SCALE ENTERPRISES IN LAGOS STATE, NIGERIA
}

\author{
Abiola O.J. ${ }^{1}$, Oluwatuyi Folorunso ${ }^{2}$, Mustapha B.H. ${ }^{1}$ and Funmilayo Busayo ${ }^{1}$ \\ ${ }^{1}$ Federal College of Animal Health and Production Technology Ibadan, \\ ${ }^{2}$ Air Force Institute of Technology Kaduna \\ olanrewajuabiola@gmail.com, oluwatuyif5@gmail.com, b.akinola12@gmail.com, \\ busayo91@yahoo.com
}

Cite this article:

Abiola O.J., Oluwatuyi F., Mustapha B.H., Funmilayo B. (2021), Liquidity Management Practices of Small and Medium-Scale Enterprises in Lagos State, Nigeria. British Journal of Management and Marketing Studies 4(3), 30-38. DOI: 10.52589/BJMMSYSOY5O9T.

\section{Manuscript History \\ Received: 6 June 2021 \\ Accepted: 3 July 2021 \\ Published: 24 July 2021}

Copyright $\odot 2020$ The Author(s). This is an Open Access article distributed under the terms of Creative Commons AttributionNonCommercial-NoDerivatives 4.0 International (CC BY-NC-ND 4.0 ), which permits anyone to share, use, reproduce and redistribute in any medium, provided the original author and source are credited.
ABSTRACT: The study investigated the extent of liquidity management practices among Small and Medium-Scale Enterprises in Lagos State, Nigeria. The study made use of primary data and the population of the study comprised of 4,460 registered Small and Medium-Scale Enterprises in Lagos State based on the Nigerian government contacts database (2015). Using Taro Yamane's formula, a sample size of 367 Small and Medium-Scale Enterprises was computed for questionnaire administration. In each Small and Medium Enterprises that was randomly sampled, questionnaires were administered to the respondents; Owner, Supervisor or Financial Manager who provided the necessary information on liquidity management practices of their firms. Data collected from the study were analysed with the use of appropriate descriptive statistics. The result of the study revealed that SMEs engaged in liquidity management practices such as cash budget (97\%), bank account operation (77\%), investment in current assets (67\%), and making current assets available for immediate conversion into cash (71\%). Use of mechanisms in the realisation of sundry debtors (64\%) and collection of debts due (64\%). The study, therefore, recommended that regulatory authorities should put in place an appropriate policy with compliance measures to check high volume cash transactions and cash hoarding prevalent in the economy.

KEYWORDS: Liquidity Management Practices, Small and Medium-Scale Enterprises, Cash, Credit Management. 


\section{INTRODUCTION}

One of the important decisions of many business organisations is cash or liquidity management. Liquidity management can be defined as the measures put in place by a business firm to control its cash assets and its related components in order to maintain optimum cash level. The recognition is simply because, without cash or the liquid assets that are necessary to operate on a daily basis, the company risks becoming insolvent and failing (Grondin \& Cieply, 1999). The good management of liquidity management leads to the solvency of firms' and also the survival of firms in a short time period. Efficient management creates competitive advantages for firms' as firms respond at the appropriate times to unobservable situations of the market in the form of interest rates and prices of raw materials.

Credit management as a concept is a structured approach to managing uncertainties through risk assessment, developing strategies of mitigation using managerial resources (Abdullahi, 2013). In every firm, a minimum amount of net working capital is required for financing the current assets, which is permanent. Therefore, the management must determine the extent to which current assets should be financed with equity funds or borrowed funds. The literature of finance has neglected the short-term financial decisions, which is working capital management. Shortage of funds for working capital as well as the over-expansion of working capital has resulted in many businesses failing and in many cases have reduced their growth. Especially, in small scale organisations, liquidity management might be the factor that decides success or failure; in larger firms, efficient liquidity management can significantly affect the firm risk, return and share (Gitman and Sachdeva 1982 in Bolek 2013). Researchers have analysed investments, capital structure, dividends and company valuation. However, the investment that firm's make in current assets and the resources used for short term investment represent the main share of assets on a firm's balance sheet which seems to have been relatively neglected in the research field. Working capital management is related to decisions regarding the management of current assets and current liabilities.

In addition, cash is seen as the vital component of the working capital because it keeps a business running. It is the hub around all financial matters centres. Thus, the management of cash (liquid) is crucial for the success of an enterprise. The adequacy of cash and other current assets, together with their efficient handling, virtually determines the survival or extinction of a business concern. Cash is regarded as the most important current asset for the operation of a business (Olowe, 1998 cited in Isibor, Modebe, Okoye and Ado 2017). It is the basic input needed to keep the business running on a continuous basis (Abu, 2005).

All over the world, Small and Medium-Scale Enterprises (SMEs) are considered the backbone of a country's economy. They play a key role in economic development and make an important contribution to employment and GDP, and are important contributors to total employment and job creation. In Jordan, SMEs comprise $98.5 \%$ of the total amount of registered companies, and $60 \%$ of formal jobs, in addition to 50\% of the GDP in 2013 and they are the engine of solving the unemployment. Cash is used to pay business obligations. Cash management assumes more importance than any other current asset and the major aim is to maintain adequate control over cash position to keep the firm with sufficient liquid and use the excess cash in some profitable way. Cash is a vital component of working capital because it keeps a business running. It is the hub around all financial matters centres. Thus, the management of cash is crucial for the success of an enterprise. 
The adequacy of cash and other current assets, together with their efficient handling, virtually determines the survival or extinction of a business concern. Cash is an important current asset for the operations of the business. It is the basic input needed to keep the business running on a continuous basis (Abu, 2005). No business operation is isolative of cash management. Cash is regarded as the most important current asset for the operation of the business (Olowe, 1998 in Isibor et al 2017). Cash is the basic input required to keep the business running. Studies have shown that financial management in SMEs is often different to that found in large firms due to the more dynamic nature of their cash flow cycle, general paucity of working capital, and their ability to risk finance through debt or equity (Ekanem, 2010). SMEs also lack the financial management and accounting systems available to large firms as well as the professional staff who manage such systems. Typically, the owner-manager is required to perform these tasks, often, but not always, with support from a bookkeeper and accountant. This is a pattern found throughout the world, both within the advanced economies that comprise the organisation for economic cooperation and development group of nations and the developing economies (Abanis, Arthur and Ssekajugo 2013; Amoako, 2013).

However, businesses that invest heavily in inventory and account receivables can suffer low profits due to an inverse relationship between liquidity and profitability. To achieve sound health of the Small and Medium-Scale Enterprises (SMEs) sector, there is a need to put in place good credit (liquidity) management system in place. Poor credit management could lead to financial losses in the SME sector therefore, there is a need for evidence in the literature.

Small and Medium-Scale Enterprises (SMEs) remain the most dynamic force and agent of economic growth and development of a nation. Small and medium scale enterprises generate at least $60 \%$ of the USA GDP (Ovia, 2001). In Nigeria, the SMEs are all around us, the fact that only a few amount is required to start SMEs make it the most popular term of business. SMEs constitute the major breakthrough in several emerging sectors. Most breakthroughs in (IT) in the U.S.A were propelled by SMEs. Microsoft Disk Operating System (MS-Dos) which enabled about $80 \%$ of the world PCS to operate was developed in 1980 by Bill Gates and Paul Allen when their company was a small scale enterprise. In India, the IT industry exported about 6 billion softwares and related services in the year 2000. This amount is just a little less than Nigeria's oil revenue of $\$ 9$ billion for the same period (Ovia, 2001).

However, it was reported that several SMEs in Nigeria fail in a little time after they are started; most fail due to poor financial management especially the working capital management. Studies indicate that many developing economies business firms including Nigeria do not see the necessity of ensuring efficient working capital management, the use of formal accounting systems, credit management and cash flow monitoring is largely ad-hoc and informal in nature (Orobia, Warren and John 2013; Mungal and Garbharram, 2014). In some of these developing economies, it is not mandatory for SMEs to keep financial records despite empirical evidence provided by cash flow monitoring.

Also, the literature indicates that there are industry benchmarks to which firms adhere when setting their capital investment policies, opinions have however been divergent. Drever and Hutchinson (2007) posit that the amount of liquidity an SME require may depend on its age, size, industry, availability of owner-managers collateral and whether it has access to bank overdraft facilities. Patrick and Udo (2009) observed that liquidity management is associated with all elements of tied-up capital across the balance sheets- fixed assets, inventories, receivables, payables and cash. While OECD, 2010; Abaniset al., 2013; Amoako, 2013; 
identified lack of financial management and professional staff as factors influencing liquidity management among SMEs. The few empirical studies that were conducted in the developing world concentrated majorly on banking and manufacturing sectors, thereby neglecting Small and Medium-Scale Enterprises which constitute major sectors of the economy, hence this study. This study is, therefore, focused on providing answers to the extent to which SMEs in Lagos state manage their liquidity.

\section{Methodology}

A descriptive research design was adopted for this study. A total of 4,460 registered small and medium scale businesses in Lagos state constituted the study population and 367 respondents were randomly selected to constitute the sample size. A validated questionnaire was used to collect data for the study. A total of 367 questionnaires were randomly administered to the small and medium scale businesses in Lagos state with the help of research assistants. Out of the 367 questionnaires that were returned and collated, two hundred and forty (240) copies were found useful for the study. Statistical Packages for Social Sciences software was used to analyse data using descriptive statistics such as frequency, percentage, the mean and standard deviation to test the research question.

\section{RESULTS}

The table showed that $47.9 \%$ of the respondents were males while $52.1 \%$ were female which implies that the majority of the respondents operating the SMEs were females. By academic qualifications, 98(41.0\%) were OND/Diploma/NCE holders, 75(31.0\%) were products with Bachelor degrees (B.sc; B. A. etc), and 39 (16.3\%) were postgraduate with Masters' Degree and $\mathrm{PhD}$ degrees. While others including Secondary School Certificate holders or less constituted $28(11.7 \%)$. In terms of work experience, $81(33.8 \%)$ were in the range of 1-5 years, $15(6.3 \%)$ were in the range of 6-10 years, $30(12.5 \%)$ in the range of $11-15$ years, $111(46.3 \%)$ were in the range of 16-20 years while $3(1.3 \%)$ were above 20 years of work experience. This implies that the majority of the SME operators in the study area have been in business between six and ten years. Besides, the table also reveals that $113(47.1 \%)$ were the owners of their business, while $58(24.2 \%$ ) were financial managers in the various selected SMEs and $69(28.8 \%)$ of the respondents were working as supervisors in the selected SMEs. This implies that the majority of the respondents were the owners of their businesses.

The table revealed that $67(27.9 \%)$ belong to the group below 30 years, $54(22.5 \%)$ fall under the group 31-40 years, 95(39.6\%) also fall under the group 41-50 years, 18 (7.5\%) fall under the group 51-60 years, while $6(2.5 \%)$ of the respondents were 61 years and above. The table also revealed the years of establishment of the selected SMEs. The table showed that 117 $(48.8 \%)$ were below ten years of establishment, 92 (38.3\%) fall under the group 11-20 years of establishments $22(9.2 \%)$ fall under the group 21-30 years, 9 (3.8\%) fall within the 21-30 years while $9(3.8 \%)$ of the SMEs had been established between 31-40 years. 
British Journal of Management and Marketing Studies

ISSN: 2689-5072

Volume 4, Issue 3, 2021 (pp. 30-38)

www.abjournals.org

Socio-Demographic Distribution of Respondents

\begin{tabular}{|c|c|c|c|}
\hline Variables & Categories & Frequencies & $\%$ \\
\hline \multirow[t]{2}{*}{ Gender } & Male & 115 & 47.9 \\
\hline & Female & 125 & 52.1 \\
\hline \multirow{4}{*}{ Academic Qualifications } & OND/NCE/DIPLOMA & 98 & 41.0 \\
\hline & B.SC & 75 & 31.0 \\
\hline & POSTGRADUATE & 39 & 16.3 \\
\hline & OTHERS (Specify) & 28 & 11.7 \\
\hline \multirow{5}{*}{$\begin{array}{l}\text { Work } \\
\text { Experience }\end{array}$} & 1 - 5 Years & 81 & 33.8 \\
\hline & $6-10$ Years & 15 & 6.3 \\
\hline & $11-15$ Years & 30 & 12.5 \\
\hline & 16 - 20 Years & 111 & 46.3 \\
\hline & Above 20 Years & 3 & 1.3 \\
\hline \multirow{3}{*}{ Rank/Status } & Owner & 113 & 47.1 \\
\hline & Financial Manager & 58 & 24.2 \\
\hline & Supervisor & 69 & 28.8 \\
\hline \multirow{5}{*}{ Age Bracket } & Below 30 Years & 67 & 27.9 \\
\hline & $31-40$ Years & 54 & 22.5 \\
\hline & $41-50$ Years & 95 & 39.6 \\
\hline & 51 - 60 Years & 18 & 7.5 \\
\hline & 61 Years and above & 6 & 2.5 \\
\hline \multirow{4}{*}{ Year of Establishment } & Below 10 Years & 117 & 48.8 \\
\hline & 11 - 20 Years & 92 & 38.3 \\
\hline & 21 - 30 Years & 22 & 9.2 \\
\hline & $31-40$ Years & 9 & 3.8 \\
\hline
\end{tabular}

Source: Field Survey, 2017 
British Journal of Management and Marketing Studies

ISSN: 2689-5072

Volume 4, Issue 3, 2021 (pp. 30-38)

www.abjournals.org

Table 1: Respondents' views on Liquidity Management practices of their firms

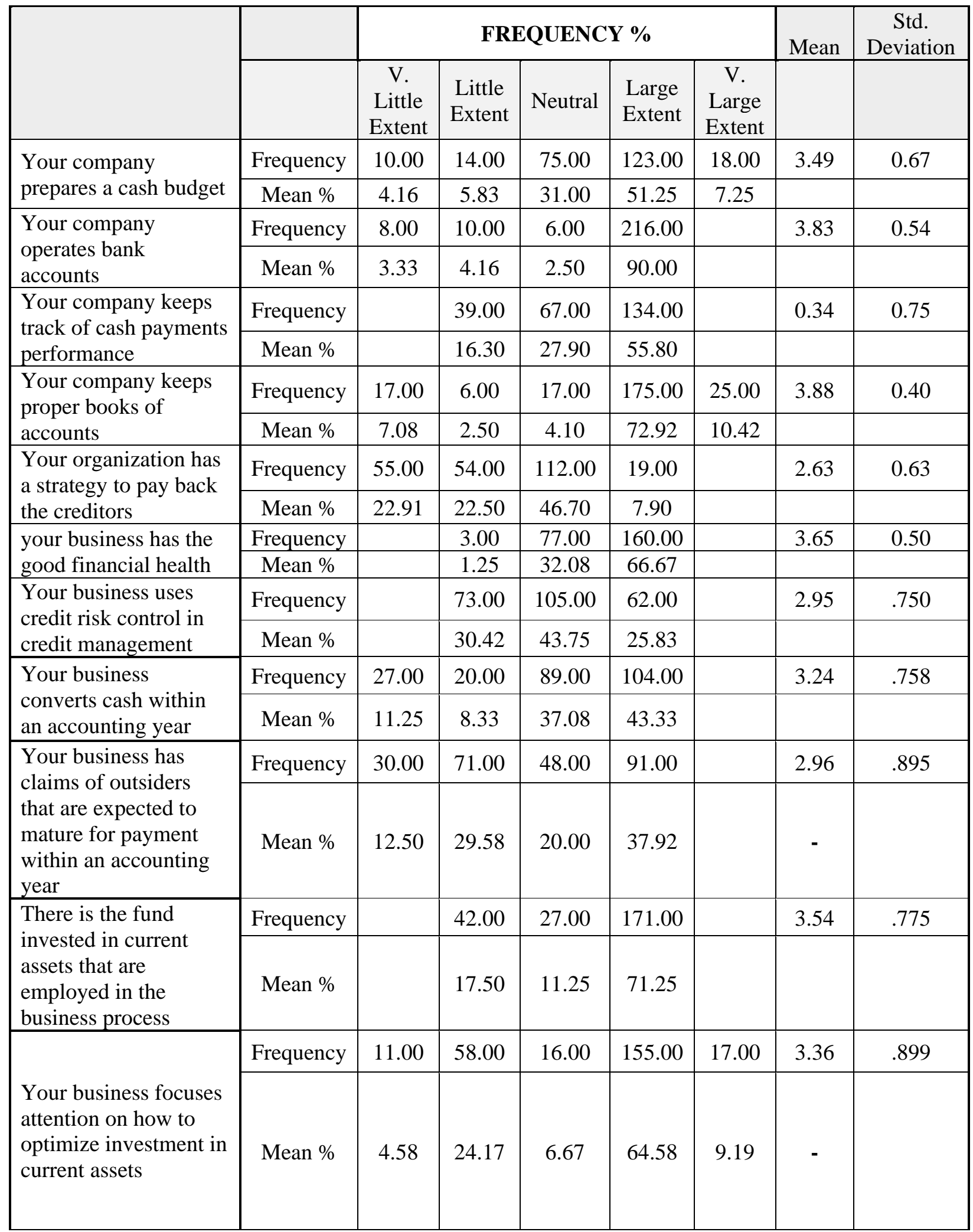


British Journal of Management and Marketing Studies

ISSN: 2689-5072

Volume 4, Issue 3, 2021 (pp. 30-38)

www.abjournals.org

\begin{tabular}{|c|c|c|c|c|c|c|c|c|}
\hline & & $\begin{array}{c}\mathrm{V} . \\
\text { Little } \\
\text { Extent }\end{array}$ & $\begin{array}{l}\text { Little } \\
\text { Extent }\end{array}$ & Neutral & $\begin{array}{l}\text { Large } \\
\text { Extent }\end{array}$ & $\begin{array}{c}\mathrm{V} . \\
\text { Large } \\
\text { Extent }\end{array}$ & Mean & $\begin{array}{c}\text { Std. } \\
\text { Deviation }\end{array}$ \\
\hline \multirow{2}{*}{$\begin{array}{l}\text { Your business has a } \\
\text { mechanism of } \\
\text { quickness in the } \\
\text { realization of sundry } \\
\text { debtors }\end{array}$} & Frequency & & 61.00 & 42.00 & 108.00 & 29.00 & 3.20 & .818 \\
\hline & Mean \% & & 17.50 & 17.50 & 45.00 & 12.10 & & \\
\hline \multirow{2}{*}{$\begin{array}{l}\text { There is effectiveness } \\
\text { in a collection of debts } \\
\text { due in your business }\end{array}$} & Frequency & & 60.00 & 40.00 & 93.00 & 47.00 & 3.14 & .788 \\
\hline & Mean $\%$ & & 25.00 & 16.70 & 38.75 & 19.60 & & \\
\hline \multirow{2}{*}{$\begin{array}{l}\text { Your business } \\
\text { maintains a balance } \\
\text { between the debtors } \\
\text { outstanding and the } \\
\text { number of interests } \\
\text { incurred }\end{array}$} & Frequency & 27.00 & 51.00 & 73.00 & 89.00 & & 3.05 & .835 \\
\hline & Mean \% & 11.25 & 21.25 & 30.42 & 37.08 & & & \\
\hline \multirow{2}{*}{$\begin{array}{l}\text { Your business has } \\
\text { measures for the } \\
\text { financial condition }\end{array}$} & Frequency & & & 43.00 & 197.00 & & 3.82 & .384 \\
\hline & Mean $\%$ & & & 17.92 & 82.08 & & & \\
\hline \multirow{2}{*}{$\begin{array}{l}\text { There are current } \\
\text { assets convertible into } \\
\text { cash immediately at a } \\
\text { short time in the } \\
\text { company }\end{array}$} & Frequency & & 27.00 & 25.00 & 188.00 & & 3.67 & .669 \\
\hline & Mean $\%$ & & 11.25 & 10.42 & 78.33 & & & \\
\hline \multirow{2}{*}{$\begin{array}{l}\text { Your business has the } \\
\text { ability to meet its } \\
\text { current liabilities }\end{array}$} & Frequency & & 43.00 & 21.00 & 176.00 & & 3.55 & .780 \\
\hline & Mean \% & & 17.92 & 8.75 & 73.33 & & & \\
\hline \multirow{2}{*}{$\begin{array}{l}\text { There is a supplement } \\
\text { to the current ratio in } \\
\text { analyzing liquidity in } \\
\text { the company }\end{array}$} & Frequency & 9.00 & 46.00 & 102.00 & 83.00 & 50.00 & 3.08 & .827 \\
\hline & Mean $\%$ & 3.75 & 19.17 & 42.50 & 34.58 & 27.03 & & \\
\hline
\end{tabular}

Source: Field Survey, 2017

Table 1 showed the extent of liquidity management practice among SMEs in Lagos state. A total of eighteen liquidity management strategies or practices were considered.

The table revealed that SMEs were preparing cash budget to a little extent in respect of liquidity management $(\chi=3.49$; SD $=0.67)$; operate bank account in managing their liquidity $(\chi=3.83$; $\mathrm{SD}=0.54)$; SMEs were keeping track of cash payment performance $(\chi=0.34$; $\mathrm{SD}=0.75)$; company keeps proper books of accounts $(\chi=3.88 ; \mathrm{SD}=0.40)$; establish strategies to pay back their creditors $(\chi=2.63$; SD $=0.63)$; convert cash within an accounting year $(\chi=3.24 ; \mathrm{SD}=$ $0.76)$; business has good financial health $(\chi=3.65$; $\mathrm{SD}=0.50)$; Your business uses credit risk control in credit management $(\chi=2.95 ; \mathrm{SD}=0.75)$; Your business has claims of outsiders that are expected to mature for payment within an accounting year $(\chi=2.96$; $\mathrm{SD}=0.90)$; there is fund invested in current assets that are employed in the business process to enhance the 
business liquidity $(\chi=3.54 ; \mathrm{SD}=0.78)$; focused their attention on how to optimize investment in current assets $(\chi=3.36$; SD $=0.90)$; SMEs have mechanism of quickness in realisation of their sundry debtors $(\chi=3.20$; SD $=0.82)$; SMEs engage effective collection of debts due $(\chi=$ 3.14; $\mathrm{SD}=0.79$ ); business maintains a balance between the debtors outstanding and the amount of interests incurred $(\chi=3.05 ; \mathrm{SD}=0.84)$; Your business has measures for financial condition $(\chi=3.82 ; \mathrm{SD}=0.38)$; SMEs have current assets convertible to cash immediately at a short time $(\chi=3.67$; $\mathrm{SD}=0.67)$; ability to meet its current liabilities $(\chi=3.55$; $\mathrm{SD}=0.78)$; SMEs have supplement to the current ratio in analysing liquidity in their business enterprises $(\chi=$ 3.08; $\mathrm{SD}=0.83$;

The implication of this result is that SME's majorly engage in keeping proper books of accounts, operate a bank account in managing their liquidity while they least engage in keeping track of cash payments performance.

\section{DISCUSSION OF FINDINGS}

The findings of this study revealed that among the eighteen liquid management practices of SMEs examined, seventeen of these practices were well adopted by the SMEs with the exception of one where they performed poorly. Among the practices where they performed well include their engagement in keeping proper books of accounts, operating a bank account in managing their liquidity among others while they least engaged in keeping track of cash payment performance. This shows that SMEs performed highly in the extent to which they adopted liquidity management practices. However, this finding is inconsistent with the findings of Nayak and Greenfield (1994) cited in Ekanem (2010) who argued that owner-managers in their survey of 200 small firms in the West Midlands did not use liquidity management techniques very effectively. Similarly, Ibe (2013) in a study on liquidity management and profitability of banks reported that cash and short term fund have not been properly managed in firms which means that the amount held may have been in excess of the requirement for greater performance since cash is sterile. This goes to show that liquid management practices among SMEs are well carried out to a large extent although a lot of work still needs to be done in ensuring in keeping track of cash payments and how well it performs and keeps the business afloat.

\section{CONCLUSION AND RECOMMENDATION}

The study concluded that SMEs in Nigeria successfully adopted liquidity management practices in the areas of cash conversion cycles, current ratios, working capital, debtor turnover ratio, and acid test ratio.

1. The regulatory authority should put in place an appropriate policy with compliance measures to check high volume cash transactions and cash hoarding prevalent in the economy. This is important because liquidity management is cumbersome and may be ineffective in an economy that operates solely on a large volume of cash transactions or conducts a large proportion of its transactions in cash. 


\section{REFERENCES}

Abanis, T., Arthur, S. \& Ssekajugo, T. (2013). Financial management practices and business performance of small and medium enterprises in western Uganda. African Journal of Business Management. 7 (38), 3875-3885.

Abdulahi, A. M., \& Worthington, A.C. (2013) "Small and Medium-Sized Enterprises Financing: A Review of the Literature," International Journal of Business and Management, 8(4), 36-54.

Abu, T. A. (2005). Cash Management of the Selected Jordanian Large Scale Public Limited Industrial Companies, Dirasat, Administrative Sciences, 32(1).

Amoako, G.K. (2013). Accounting Practices of SMEs: A Case Study of Kumasi Metropolis in Ghana, International Journal of Business and Management, Canadian Center of Science and Education, 8 (24).

Bolek, M. (2013). Profitability as a liquidity and risk function basing on the new connect market in Poland. European Scientific Journal, 9(28):1-15.

Drever, M. F., \& Hutchinson, P. (2007). Industry Differences in The Determinants of the Liquidity of Australian Small and Medium-Sized Enterprises. Small Enterprise Research, 15(1), 60-76.

Ekanem, I. (2010). Liquidity management in small firms: a learning perspective. Journal of Small Business and Enterprise Development 17 (1): pp. 123-138.

Gitman, I. and Sachdeva, K. S. (1982). A framework for estimating and analysing the required working capital investment. Review of Business and Economic Research 7(3):36-44.

Grondin, M., \& Cieply, S. (1999) Expertise et contrôle des risques - PME par le chargé de clientèleentreprises:une alternative au rationnement. Revue d'économiefinancière: 5978.

Ibe, S. O. (2013). The Impact of Liquidity Management on the Profitability of Banks in Nigeria. Journal of Finance and Bank Management 1(1); pp. 37-48.

Isibor, A., Modebe, N. J., Okoye, L. U. and Ado, A. (2017). Dividend policy and value of the firm: Is dividend relevant or not? ESUT Journal of Accountancy 8(1): pp1-10.

Mungal, A., \&Garbharran, H.L. (2014) The perceptions of small businesses in the implementation of cash management techniques, Journal of Economics and Behavioral Studies, 6 (1) 75-83.

Nayak, A. and Greenfield, S. (1994), "The use of management accounting information for managing micro-businesses", in Hughes, A. and Storey, D. (Eds), Finance and the Small Firm, Routledge, London, pp. 182-231.

Olowe, R. A. (1998). Financial management concepts, analysis and capital investment, Lagos. Demak Publishers.

Orobia AO, Warren B, John CM (2013). How Do Small Business Owners Manage Working Capital in an Emerging Economy? A Qualitative Inquiry. Emerald Group Publishing.

Ovia J. (2001). Financing Information and Communication Technology: Opportunities and Constraints at the African IT exhibitions and Conferences venue held at the Eko le Meridien Hotel Lagos. 